\title{
Premature Activation of Indicator
}

National Cancer Institute

\section{Source}

National Cancer Institute. Premature Activation of Indicator. NCI Thesaurus. Code C62865.

Problems with the activation of a protective measure indicator earlier than expected. 